\title{
Profil Biokimia Darah Sapi Aceh yang Mengalami Kawin Berulang
}

\author{
(THE BLOOD BIOCHEMICAL PROFILE \\ IN ACEH COWS WITH REPEAT BREEDING)
}

\section{Cut Nila Thasmi ${ }^{1}$, Husnurrizal ${ }^{1}$, Muslim Akmal ${ }^{2}$, Sri Wahyuni ${ }^{3}$, Tongku Nizwan Siregar ${ }^{1}$}

\author{
${ }^{1}$ Laboratorium Reproduksi; ${ }^{2}$ Laboratorium Histologi; \\ ${ }^{3}$ Laboratorium Anatomi, Fakultas Kedokteran Hewan, \\ Universitas Syiah Kuala, \\ Jln Tgk Hasan Krueng Kalee No 4 \\ Darusalam, Banda Aceh,Indonesia, 23111 \\ Telpon: (0651)7551536, \\ Email: cutnilathasmi@unsyiah.ac.id
}

\begin{abstract}
ABSTRAK
Tujuan penelitian ini adalah mengetahui profil biokimia darah sapi aceh yang mengalami kawin berulang/repeat breeding (RB). Dalam penelitian ini digunakan 16 ekor sapi aceh yang terdiri atas tujuh ekor sapi aceh fertil dan sembilan ekor sapi aceh RB, yang berumur 3-8 tahun dengan skor kondisi tubuh (SKT) 3-4. Koleksi serum dilakukan untuk pemeriksaan profil biokimia darah meliputi kadar kolesterol, protein, dan glukosa. Kadar kolesterol; protein; dan glukosa sapi aceh fertil vs RB masing-masing adalah $185,86 \pm 45,34$ vs $144,00 \pm 40,69 \mathrm{mg} / \mathrm{dL} ; 6,57 \pm 1,55$ vs $6,96 \pm 2,05 \mathrm{~g} / \mathrm{dL}$; dan $67,43 \pm 13,72$ vs $73,78 \pm 15,83 \mathrm{mg} /$ dL. Disimpulkan bahwa kadar glukosa sapi aceh RB lebih tinggi dibandingkan sapi fertile, sedangkan kadar kolesterol dan protein relatif sama.
\end{abstract}

Kata-kata kunci: sapi aceh; profil biokimia; repeat breeding; kawin berulang

\begin{abstract}
This study aims to determine the blood biochemical profile of Aceh cows with repeat breeding (RB). Data were obtained from seven fertile and nine RB cows, between the ages of 3-8 years with a body condition score (BCS) ranging between 3-4. Serum collection was carried out to check their blood biochemical profile, cholesterol, protein, and glucose. The total cholesterol, protein, and glucose level in fertile vs RB Aceh cows is $185.86 \pm 45.34$ vs $144.00 \pm 40.69 \mathrm{mg} / \mathrm{dL}, 6.57 \pm 1.55$ vs $6.96 \pm 2.05 \mathrm{~g} / \mathrm{dL}$, and $67.43 \pm 13.72$ vs $73.78 \pm 15.83 \mathrm{mg} / \mathrm{dL}$, respectively. In conclusion, the glucose level of RB Aceh cows was higher than those that are fertile, while the cholesterol and protein were in the same level.
\end{abstract}

Keywords: Aceh cows; biochemical profile; repeat breeding

\section{PENDAHULUAN}

Salah satu permasalahan reproduksi yang terjadi pada sapi aceh adalah rendahnya efisiensi reproduksi (Thasmi et al., 2016). Rendahnya efisiensi reproduksi mengindikasikan adanya gangguan reproduksi seperti endometritis, anestrus dan kawin berulang/repeat breeding/RB (Bage et al., 2002) yang berdampak buruk pada kinerja produksi dan reproduksi sapi (Prihatno et al., 2013). Tingginya jumlah ternak sapi yang diafkir mencapai 35,2\% dan mengakibatkan kerugian ekonomi yang besar bagi peternak sapi (Bonneville-Hebert et al., 2011). Menurut Kumar (2014) penyebab dasar dari permasalahan reproduksi pada sapi adalah faktor manajemen, nutrisi, dan patologis. 
Salah satu penyebab RB adalah kesalahan manajemen, terutama defisiensi nutrisi (Prihatno et al., 2013). Defisiensi nutrisi atau asupan nutrisi yang tidak cukup dapat berpengaruh langsung terhadap efisiensi reproduksi yang mengakibatkan terjadinya penurunan kinerja reproduksi dan produktivitas (Kumar, 2014). Selain itu, Prihatno et al. (2013) menyatakan bahwa defisiensi nutrisi juga menyebabkan kinerja atau aktivitas ovarium menjadi tidak optimal, gangguan hormonal, dan menyebabkan calving interval menjadi panjang, yang pada akhirnya menyebabkan munculnya gangguan RB.

Kejadian RB pada sapi disebabkan oleh banyak faktor di antaranya faktor manajemen pemeliharaan, nutrisi, infeksi, dan hormonal (Barui et al., 2015; Ramandani dan Nururrozi, 2015; Matubber Matubber et al., 2018). Defisiensi nutrisi telah dilaporkan sebagai faktor utama penyebab gangguan reproduksi pada sapi perah (Kumar, 2014; Barui et al., 2015; Ahmed et al., 2017; Sulieman et al., 2017), dan kerbau (Akhtar et al., 2014; Saraswat dan Purohit, 2016). Ramandani dan Nururrozi (2015) mengemukakan bahwa defisiensi atau ketidakseimbangan nutrisi dapat berpengaruh buruk terhadap berbagai tahap proses reproduksi.

Konsentrasi glukosa dan total protein darah pada sapi perah yang mengalami RB lebih rendah dibanding sapi normal (Barui et al., 2015; Ahmed et al., 2017; Sulieman et al., 2017). Rendahnya konsentrasi glukosa darah dan total protein menyebabkan terjadinya gangguan hormonal (Barui et al., 2015) yaitu dapat menghambat sintesis atau pelepasan gonadotropine releasing hormone/ $\mathrm{GnRH}$, dan menghambat pelepasan folicle stimulating hormone/FSH dan luteinizing hormone/LH, menyebabkan terhambatnya pelepasan estradiol, dan progesteron serta terhambatnya perkembangan folikel dan ovum. Selain itu, juga berdampak pada kematian ovum, embrio, dan fetus karena tidak cukupnya hormon steroid yang dihasilkan oleh ovarium (Prihatno et al., 2013). Lebih lanjut, kondisi ini menyebabkan kegagalan fertilisasi dan kematian embrio dini (Ramandani dan Nururrozi, 2015).

Prihatno et al. (2013) dan Yuherman et al. (2017) menjelaskan bahwa rendahnya profil biokimia serum darah terutama total kolesterol, kadar glukosa darah, dan kalsium menandakan rendahnya nutrisi dalam ransum yang diberikan, baik dari segi kualitas maupun kuantitas. Kondisi tersebut sangat berpengaruh terhadap sistem reproduksi. Menurut Jainudeen dan Hafez (2000), defisiensi nutrisi dalam ransum dapat memengaruhi proses ovulasi dan fertilisasi, perkembangan embrio dan fetus di dalam uterus, yang diikuti kematian embrio dan penyerapan embrio oleh dinding uterus, keluron/ abortus atau kelahiran anak yang lemah, dan kematian neonatal. Laporan tentang profil darah sapi aceh yang mengalami RB masih sangat terbatas. Oleh karena itu, penelitian ini bertujuan mengetahui gambaran profil biokimia darah pada sapi aceh yang mengalami RB dan fertil.

\section{METODE PENELITIAN}

Dalam penelitian ini digunakan 16 ekor sapi aceh yang terdiri atas tujuh ekor sapi fertil dan sembilan ekor sapi RB, berumur 3-8 tahun, dan memiliki skor kondisi tubuh (SKT) antara 3-4. Sapi fertil merupakan sapi $>2$ bulan pascapartus yang mempunyai riwayat berhasil bunting dengan sekali inseminasi dan mempunyai dua kali siklus estrus reguler, sedangkan sapi RB terdiri atas sapi yang didiagnosis mengalami RB yaitu sapi yang gagal bunting setelah lebih dari tiga kali diinseminasi namun memiliki siklus estrus normal. Jenis pakan yang diberikan kepada sapi oleh peternak adalah rumput lapangan, jerami padi segar, dan jerami padi yang sudah dikeringkan.

\section{Penyerentakan/Sinkronisasi Berahi}

Seluruh sapi aceh fertil dan RB dilakukan penyerentakan/sinkronisasi berahi dengan 25 mg PGF2á (Lutalyse ${ }^{\mathrm{TM}}$, Pfizer, Belgia) secara intramuskuler, sebanyak dua kali dengan interval waktu sebelas hari.

\section{Koleksi dan Preparasi Sampel Serum}

Koleksi darah dilakukan pada waktu pagi hari (jam 07.00-09.00 WIB) dengan suhu lingkungan rata-rata mencapai $23,6^{\circ} \mathrm{C}$. Sampel darah diambil melalui vena jugularis, lalu dimasukkan dalam tabung vacutainer dan ditempatkan dalam coolbox dalam kondisi dingin. Sampel darah kemudian dibawa ke laboratorium dan dilakukan preparasi untuk mendapatkan serum dan didiamkan selama 30 menit. Proses selanjutnya adalah sentrifugasi sampel darah dengan kecepatan $2500 \mathrm{rpm}$ selama 15 menit. Serum yang terbentuk selanjutnya dimasukkan dalam tabung 
microtube dan disimpan dalam freezer pada suhu minus $20^{\circ} \mathrm{C}$ sebelum dilakukan analisis biokimia.

\section{Pemeriksaan Biokimia Darah dan Analisis Data}

Pemeriksaan kadar kolesterol, protein, glukosa dilakukan menggunakan reagensia LabTest yang sesuai dengan parameter yang diperiksa (kolesterol, HDL-50128A; protein, glukosa, glucose liquiform 133-1/500; protein ReiGed Diagnostic, PT. RajaErba Indochem, Indonesia). Data hasil pemeriksaan yang terkumpul berupa total kolesterol, total protein, dan glukosa dianalisis dengan uji t.

\section{HASIL DAN PEMBAHASAN}

Data profil biokimia darah pada sapi aceh fertil dan RB disajikan pada Tabel 1.

Pada Tabel 1, disajikan kadar kolesterol; protein; dan glukosa sapi aceh fertil vs RB masing-masing adalah 185,86 145,34 vs $144,00 \pm 40,69 \mathrm{mg} / \mathrm{dL}(\mathrm{P}>0,05) ; 6,57 \pm 1,55$ vs $6,96 \pm 2,05 \mathrm{~g} / \mathrm{dL}(\mathrm{P}>0,05)$; dan $67,43 \pm 13,72$ us $73,78 \pm 15,83 \mathrm{mg} / \mathrm{dL}(\mathrm{P}<0,05)$. Konsentrasi kolesterol sapi fertil dan sapi RB menunjukkan perbedaan yang tidak nyata $(\mathrm{P}>0,05)$. Hal ini sesuai dengan laporan Zaman et al. (2012); Guzel dan Tanriverdi (2014), sedangkan Kumar (2014); Kekan dan Shirbhate (2015); Amle et al. (2014) melaporkan sebaliknya bahwa konsentrasi kolesterol lebih rendah pada sapi aceh RB dibandingkan sapi aceh fertil.

Meskipun secara statistika tidak terdapat perbedaan konsentrasi kolesterol antara sapi RB dengan sapi fertil namun terdapat kecenderungan konsentrasi kolesterol lebih rendah pada sapi RB. Dalam penelitian ini ditemukan tiga sapi pada kelompok sapi RB yang memiliki level kolesterol $<100 \mathrm{mg} / \mathrm{dL}$ yang dapat menjadi petunjuk bahwa kemungkinan sebagian sapi yang mengalami RB disebabkan level kolesterol yang rendah. Hasil ini sejalan dengan laporan penelitian Chandrahar et al. (2003), Prihatno et al. (2013), Kumar (2014) bahwa kadar kolesterol total pada sapi RB lebih rendah dibandingkan dengan sapi fertil. Kadar kolesterol total pada sapi aceh yang diperoleh pada penelitian ini tergolong lebih tinggi dibandingkan pada sapi perah Friesian Holstein (FH) $(125,95 \pm 38,108$ dan $166,08 \pm 37,06 \mathrm{mg} / \mathrm{dL})$ (Prihatno et al., 2013), sapi perah crossbreed $(98,90 \pm 12,48$ dan $114,14 \pm 9,72 \mathrm{mg} / \mathrm{dL}$ ) (Kumar, 2014) dan sapi Ongole crossbreed $(124,65 \pm 12,84$ dan $151,45 \pm 26,25 \mathrm{mg} / \mathrm{dL}$ ) (Widayati et al., 2018).

Nair et al. (1987) menyatakan bahwa level kolesterol pada sapi RB mempunyai korelasi positif dengan performa reproduksi. Kolesterol kemungkinan berfungsi meningkatkan performa reproduksi secara langsung dengan cara memperbaiki lingkungan uterus dan perkembangan embrio melalui peningkatan konsentrasi progesteron (Lopes et al., 2009). Kolesterol merupakan suatu zat lemak yang diproduksi di hati dan beredar di dalam darah. Kolesterol juga merupakan unsur penting dalam membran plasma, dan senyawa induk bagi semua steroid lainnya yang disintesis dalam tubuh seperti hormon korteks adrenal serta hormon reproduksi, vitamin $\mathrm{D}$, dan asam empedu (Murray et al., 2003). Selain itu, kolesterol sangat penting untuk biosintesis androstenedion, progesteron, dan estradiol oleh sel-sel granulosa di bawah pengaruh luteinizing hormone (Guzel dan Tanriverdi, 2014). Sel-sel granulosa menghasilkan pregnenolon setelah mendapat rangsangan dari LH yang selanjutnya dikonversi menjadi androstenedion oleh sel-sel teka. Sebagian besar androstenedion kembali lagi ke sel granulosa dan dikonversi kembali menjadi estron dan estradiol (Widayati et al., 2018). Rendahnya kadar hormon LH dalam

Tabel 1. Hasil uji biokimia darah pada sapi aceh fertil dan sapi aceh yang mengalami kawin berulang/repeat breeding

\begin{tabular}{lcc}
\hline & \multicolumn{2}{c}{ Sapi Aceh } \\
\cline { 2 - 3 } Profil Biokimia Darah & Fertil(n=7) & Repeat Breeding $(\mathrm{n}=9)$ \\
\hline Kolesterol $(\mathrm{mg} / \mathrm{dL})$ & $185,86 \pm 45,34^{\mathrm{a}}$ & $144,00 \pm 40,69^{\mathrm{a}}$ \\
Protein $(\mathrm{g} / \mathrm{dL})$ & $6,57 \pm 1,55^{\mathrm{a}}$ & $6,96 \pm 2,05^{\mathrm{a}}$ \\
Glukosa $(\mathrm{mg} / \mathrm{dL})$ & $67,43 \pm 13,72^{\mathrm{a}}$ & $73,78 \pm 15,83^{\mathrm{b}}$ \\
\hline
\end{tabular}

a,b Superskrip yang berbeda pada baris yang sama menunjukkan perbedaan yang sangat nyata $(\mathrm{P}<0,01)$ 
darah dapat menyebabkan terjadinya ovulasi yang tertunda atau delayed ovulation dan sistik folikel akibat rendahnya kadar $\mathrm{LH}$, fase folikuler menjadi panjang sehingga fase luteal akan tertunda atau tidak terjadi sama sekali (Suharyati dan Hartono, 2016).

Konsentrasi total protein pada sapi RB menunjukkan perbedaan yang tidak nyata dengan sapi fertil $(\mathrm{P}>0,05)$ dengan konsentrasi masing-masing adalah $6,96 \pm 2,06$ dan $6,57 \pm 1,56$ g/dL. Hasil penelitian ini berbeda dengan laporan Kumar (2014) bahwa konsentrasi serum protein sapi fertil dan sapi RB masing-masing

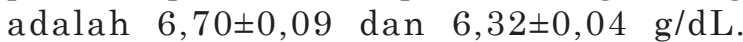
Konsentrasi protein yang rendah mengakibatkan gangguan sintesis gonadotropin (Khan et al., 2010). Hasil penelitian ini sejalan dengan laporan Cetin et al. (2002), Pathan et al. (2012), Guzel dan Tanriverdi (2014). Sapi RB adalah sapisapi yang menunjukkan siklus estrus reguler sehingga konsentrasi total proteinnya berada pada kisaran normal.

Rata-rata protein total yang diperoleh pada penelitian ini sama dengan yang dilaporkan oleh Zaman et al. (2014) dan Kumar (2014). Namun, Amle et al. (2014) melaporkan hal yang berbeda, yakni kadar protein total pada sapi RB lebih rendah daripada sapi fertil. Rendahnya kadar protein total lebih sering ditemukan pada sapi yang mengalami anestrus (Agrawal et al., 2015; Singaram dan Jacob, 2017). Kondisi ini karena defisiensi asam amino yang dibutuhkan oleh tubuh, sehingga dapat mengganggu proses biosintesis gonadotropin dan hormon gonad lainnya (Khan et al., 2010).

Konsentrasi glukosa dalam serum antara sapi fertil dan sapi RB menunjukkan perbedaan yang sangat nyata $(\mathrm{P}<0,01)$ dengan konsentrasi masing-masing adalah 67,43 $\pm 13,72$ dan $73,78 \pm 15,83 \mathrm{~g} / \mathrm{dL}$. Hasil ini berbeda dengan laporan Prihatno et al. (2013) dan Kumar (2014) yang memperoleh konsentrasi glukosa (g/dL) antara sapi fertil dan sapi RB masing-masing adalah $68,40 \pm 9,60$ vs $48,58 \pm 6,68$ dan $60,27 \pm 2,28$ vs $55,18 \pm 3,10$. Level glukosa pada kedua kelompok penelitian ini lebih tinggi dibandingkan laporan Prihatno et al. (2013), Kumar (2014), Freitas et al. (2017), dan Widayati et al. (2018). Hal ini mengindikasikan kejadian RB pada sapi aceh bukan disebabkan oleh rendahnya level glukosa. Level glukosa yang rendah memengaruhi ovum, embrio, dan fetus (Prihatno et al., 2013). Mulligan et al. (2006) menambahkan bahwa defisiensi glukosa menurunkan sekresi GnRH yang berdampak terhadap hambatan sekresi FSH dan LH. Kondisi tersebut menyebabkan gangguan keseimbangan hormonal yang merupakan salah satu penyebab terjadinya RB.

Tingginya konsentrasi glukosa darah pada sapi RB pada penelitian ini sesuai dengan laporan Awasthi dan Kharche (1987) yang melaporkan bahwa adanya kenaikan kadar glukosa pada sapi yang mengalami RB. Tingginya kadar glukosa pada sapi RB berhubungan dengan masalah reproduksi seperti endometritis (Guzel dan Tanriverdi, 2014; Sulieman et al., 2017). Ahmed et al. (2004) menemukan kadar glukosa darah sapi yang mengalami endometritis secara signifikan lebih tinggi daripada pada hewan yang memiliki siklus estrus normal dan non-siklus (masingmasing yaitu 58,08 $\pm 2,59 ; 50,72 \pm 1,12$; dan $50,56 \pm 1.13 \mathrm{~g} / \mathrm{dL})$. Peningkatan kadar glukosa darah pada sapi yang endometritis diikuti dengan peningkatan adrenokortikotropik hormon. Majeed et al. (1990) juga melaporkan hal yang sama, kadar glukosa pada sapi endometritis lebih tinggi daripada sapi yang sehat. Tingginya kadar glukosa pada penelitian ini dapat diasumsikan bahwa sapi aceh RB pada penelitian ini mengalami endometritis subklinis sehingga menyebabkan terjadinya RB.

Salah satu mekanisme infertilitas yang diduga terkait dengan endometritis yaitu adanya peningkatan spesies oksigen reaktif (ROS), perubahan fungsi sistem imun, perubahan hormonal pada ovarium, dan penurunan aktivitas endometrium (Gupta et al., 2008). Peningkatan ROS dapat terjadi akibat aktivasi makrofag oleh sistem imun tubuh. Aktivasi makrofag ini menyebabkan peningkatan penggunaan glukosa dalam darah melalui lintasan pentose fosfat yang dipakai untuk mereduksi NADP menjadi NADPH, dan peningkatan penggunaan oksigen yang dipakai untuk mengoksidasi NADPH guna menghasilkan superoksida dan halogen radikal sebagai agen yang sitotoksik untuk membunuh mikroorganisme yang telah difagosit di dalam uterus yang terinfeksi (Makker et al., 2009).

Reaksi stres oksidatif yang terjadi menyebabkan peningkatan laju peroksidasi lipid yang berkontribusi dalam produksi radikal bebas, termasuk terbentuknya anion superoksida, sehingga menyebabkan modifikasi oksidatif yang mengakibatkan terinaktivasinya superoxide dismutase (Kaya et al., 2017). Peroksidasi lipid adalah peristiwa teroksidasinya lipid yang berlangsung secara cepat (Pasaoglu 
et al., 2004). Lipid yang teroksidasi merupakan bagian fosfolipid membran sel â pankreas pada penderita diabetes mellitus sehingga memengaruhi kestabilan strukturnya. Demikian pula fungsi vital sel sebagai penyedia hormon insulin turut terganggu, karena peroksidasi lipid menyebabkan peningkatan permeabilitas membran sel. Produksi hormon insulin menjadi berkurang, demikian pula fungsinya, sehingga tidak mampu mengarahkan pemasukan glukosa ke jaringan. Kondisi tersebut menyebabkan kadar glukosa dalam darah menjadi tinggi (Robertson et al., 2004; Rahmawati et al., 2014). Selain itu, peningkatan kadar peroksidasi lipid pada hewan yang mengalami endometritis klinis menunjukkan peningkatan produksi ROS dalam leukosit. ROS menyebabkan peningkatan kadar peroksidasi lipid dan membatasi respons sistem imun tubuh dengan merusak sel-sel imun dalam tubuh (Heidarpour et al., 2012).

Menurut Suwasono et al. (2013) perubahan kadar glukosa darah disebabkan oleh aktivitas hormon insulin untuk menstabilkan kadar glukosa darah dengan cara mendorong glukosa darah menjadi glikogen hati dan otot. Lehninger (1994) menjelaskan bahwa bila kadar glukosa darah naik, hormon insulin akan meningkat sehingga mempercepat masuknya glukosa ke dalam hati dan otot, di tempat itu glukosa akan diubah menjadi glikogen. Mekanisme peningkatan glukosa darah diatur oleh hormon glukagon dari sel alpha, hormon dari hipofisa anterior, epinerprin dari medula adrenal, serta glukokortikoid dari korteks adrenal (Unitly, 2012).

Saat tubuh merespons stres maka akan dihasilkan suatu hormon glukokortikoid yaitu kortisol dari kelenjar adrenal. Produksi hormon ini diatur oleh hipofisa berupa pengeluaran adreno corticotrophic hormone (ACTH). Stres menekan fungsi reproduksi melalui hambatan jalur hipotalamus-hipofisa-gonad melalui penghambatan dari pelepasan hormon gonadotropine-releasing hormone (GnRH). Di tingkat hipofisa, efek dari kortisol merupakan efek sekunder dari penghambatan sekresi GnRH berupa penurunan produksi FSH dan ditingkat ovarium, kortisol secara langsung menghambat produksi hormon steroid dan menginduksi apoptosis.

Selain itu, peningkatan kadar glukosa dalam darah juga dipengaruhi oleh asupan pakan. Menurut Tahuk et al. (2017) faktor pakan, terutama konsumsi energi sangat menentukan tinggi rendahnya kadar glukosa darah. Kadar glukosa darah dipengaruhi oleh karbohidrat pakan, baik berupa serat kasar (SK) maupun bahan ekstrak tanpa nitrogen (BETN) yang akan memengaruhi peningkatan glukosa darah. Serat kasar dan BETN difermentasi oleh mikrob rumen menjadi volatile fatty acidl VFA dan gula-gula sederhana, kemudian disintesis menjadi glukosa darah di dalam hati (Tillman et al., 1991). Sumber glukosa pada ternak ruminansia adalah asam propionat, asam laktat, protein dan gliserol. Propionat merupakan hasil fermentasi karbohidrat di dalam rumen (Tahuk et al., 2017). Asam propionat mensuplai kebutuhan glukosa tubuh sebanyak 30\% (Parakkasi, 1999).

\section{SIMPULAN}

Disimpulkan bahwa kadar glukosa sapi aceh yang mengalami kawin berulang atau RB lebih tinggi dibandingkan sapi fertil sedangkan kadar kolesterol dan protein relatif sama.

\section{UCAPAN TERIMA KASIH}

Penulis mengucapkan terima kasih kepada Ketua LPPM dan Rektor Universitas Syiah Kuala atas kepercayaan yang diberikan melalui Hibah Guru Besar Tahun Anggaran 2016.

\section{DAFTAR PUSTAKA}

Agrawal JK, Saxena A, Singh V. 2015. Study on metabolic profile of repeat breeder, post partum anestrous and normal cyclic sahiwal cows. Indian J Anim Reprod 36(1): 53-55.

Ahmed ME, Ahmed FO, Frah EAM, Elfaki I. 2017. Blood biochemical profile of Sudanese crossbred repeat breeder cows. African $J$ Biotechnol 16(8): 366-370.

Akhtar MS, Farooq AA, Lodhi LA, Muhammad SA, Ayaz MM, Lashari MH, Murtaza S, Hussain I, Irshad M, Maqbool HM, Raza MA. 2014. Studies on serum macro and micro minerals status in repeat breeder and normal cyclic Nili-Ravi buffaloes and their treatment strategies. African J Biotechnol 13(10): 1143-1146. 
Amle M, Patodkar V, Shelar R, Birade H. 2014. Serum biochemical levels of repeat breeder cross bred cows under rural condition of Satara district of Maharashtra. Int $J$ Adv Vet Sci Technol 3(1): 109-113.

Awasthi MK, Kharche KG. 1987. Studies on some constituents in normal cycling, fertile and infertile repeat breeder crossbred cows. Indian J Anim Reprod 8(2): 95-97.

Bage R, Gustafsson H, Larsson B, Forsber M, Rodriguez-Martinez H. 2002. Repeat breeding in dairy heifers: Follicular dynamic and estrous cycle characteristics in relation to sexual hormone pattern. Theriogenology 57: 2257-2269.

Barui A, Batabyal S, Ghosh S, Saha D, Chattopadhyay S. 2015. Plasma mineral profiles and hormonal activities of normal cycling and repeat breeding crossbred cows: A comparative study. Vet World 8(1): 4245.

Bonneville-Hébert A, Bouchard E, Tremblay DD, Lefebvre R. 2011. Effect of reproductive disorders and parity on repeat breeder status and culling of dairy cows in Quebec. Can $J$ Vet Res 75(2): 147-151.

Cetin M, Dogan I, Polat U, Yalcin A, Turkyilmaz O. 2002. Blood biochemical parameters in fertile and repeat breeder cows. Indian J Anim Sci 72(10): 865-866.

Chandrahar, D., R.P. Tiwari, M.K. Awasthi, and G.K. Dutta. 2003. Serum biochemical profile of repeat breeder crossbred cows. Indian Journal of Animal Reproduction 24(2): 125127.

Freitas JDC, Widayati DT, Yusiati LM. 2017. Cortisol Hormones Profiles of Repeat Breeding Local Cattle. Proceding. The 7th International Seminar on Tropical Animal Production (ISTAP). Faculty of Animal Science Universitas Gajah Mada. Yogyakarta. Hlm. 35-38.

Gupta S, Goldberg JM, Aziz N, Goldberg E, Krajcir N, Agarwal A. 2008. Pathogenic mechanisms in endometriosis-associated infertility. Fertil Steril 90(2): 247-257.

Guzel S, Tanriverdi M. 2014. Comparison of serum leptin, glucose, total cholesterol and total protein levels in fertile and repeat breeder cows. Rev Bras Zootec 43(12): 643 647.
Heidarpour M, Mohrý M, Fallah-Rad AH, Shahreza FD, Mohammadi M. 2012. Oxidative stress and trace elements before and after treatment in dairy cows with clinical and subclinical endometritis. Revue Méd Vét 163(12): 628-633.

Jainudeen MR, Hafez ESE. 2000. Cattle and Buffalo. In Reproduction in Farm Animals. Hafez B, ESE. Hafez (Eds.). $7^{\text {th }}$ Ed. Philadelphia. Lippincott Williams \& Wilkins, Hlm. 87-92.

Kaya S, Öðün M, Özen H, Kuru M, aahin L, Kükürt A, Kaçar C. 2017. The impact of endometritis on specific oxidative stress parameters in cows. J Hellenic Vet Med Soc 68(2): 231-236.

Kekan PM, Shirbhate RN. 2015. Biochemical status during oestrus cycle in regular and repeat breeding cows. Theriogenology Insight 5(3): 213-217.

Khan S, Thangavel A, Selvasubramaniyan S. 2010. Blood biochemical profile in repeat breeding cows. Tamilnadu J Vet Anim Sci 4: 90-102.

Kumar AS. 2014. Blood biochemical profile in repeat breeding crossbred dairy cows. Int $J$ Vet Sci 3(4): 172-173.

Lehninger AL. 1994. Dasar-dasar Biokimia. Jilid 3. Jakarta. Penerbit Erlangga, Hlm. 34-42.

Lopes CN, Scarpa AB, Cappellozza BI, Cooke RF, Vasconcelos JLM. 2009. Effects of rumenprotected polyunsaturated fatty acid supplementation on reproductive performance of Bos indicus beef cows. $J$ Anim Sci 87: 3935-3943.

Majeed MA, Iqbal J, Chaudhry MN. 1990. Blood chemistry of clinical merits in Nili-Ravi buffaloes of two age groups and at two stages of lactation. Pakistan Vet J 10(2): 55-59.

Makker K, Agarwal A, Sharma R. 2009. Oxidative stress and male infertility. Indian J Med Res 129: 357-367.

Matubber B, Paul AK, Das S. 2018. Evaluation of different parameters in relation to repeat breeding of cows at the coastal areas of Bangladesh. Res Agricult Livest Fisher 5(1): 49-55

Mulligan FJ, O'Grady L, Rice DA, Doherty ML. 2006. Nutrition and fertility in dairy cows. Irish Vet J 60: 15-20. 
Murray RK, Granner DK, Mayes PA, Rodwell VW. 2003. Biokimia Harper. Edisi ke-25. Jakarta. Penerbit Buku Kedokteran EGC, Hlm. 54-58.

Nair S, Kharche KG, Shirvastava OP. 1987. Study on blood glucose and cholesterol in normal and abnormal cycling crossbred cows. Indian J Anim Reprod 8: 12-13.

Parakkasi A. 1999. Ilmu Nutrisi dan Makanan Ternak Ruminan. Cetakan Pertama. Jakarta. Penerbit UIP. Hlm. 21-24.

Pasaoglu H, Sancak B, Bukan N. 2004. Lipid peroxidation and resistance to oxidation in patients with type 2 diabetes mellitus. Tohoku J Exp Med 203(3): 211-218.

Pathan MM, Das H, Khan MJZ, Shiddique GM, Latif A, Parsani HR. 2011. Comparative studies on haemato-biochemical profile of cyclic and non-cyclic Holstein-Friesian crossbred cows. Wayamba J Anim Sci. 20: 69-74.

Prihatno SA, Kusumawati A, Karja NWK, Sumiarto B. 2013. Profil biokimia darah pada sapi perah yang mengalami kawin berulang. J Kedokt Hewan 7(1): 29-31.

Rahmawati G, Rachmawati FN, Winarsi H. 2014. Aktivitas superoksida dismutase tikus diabetes yang diberi ekstrak batang kapulaga dan glibenklamid. Scripta Biol 1(3): 197-201.

Ramandani D, Nururrozi A. 2015. Kadar glukosa dan total protein plasma pada sapi yang mengalami kawin berulang di wilayah Daerah Istimewa Yogyakarta. J Sain Vet 33(1): 23-28.

Robertson RP, Harmon J, Tran PO, Poitout V. 2004. Â-cell glucose toxicity, lipotoxicity, and chronic oxidative stress in type 2 diabetes. Diabetes 53(1): 119-124.

Saraswat CS, Purohit GN. 2016. Repeat breeding: Incidence, risk factors and diagnosis in buffaloes. Asian Paciûc $J$ Reproduct 5(2): 87-95.

Singaram B, Jacob T. 2017. Comparative studies on blood biochemical profile of anestrus and normal cyclic jersey cross-breed cows. Int $J$ Livest Res 7(3): 40-44.

Suharyati S, Hartono M. 2016. Pengaruh manajemen peternak terhadap efesiensi reproduksi sapi bali di Kabupaten Pringsewu Provinsi Lampung. J Penelitian Pertanian Terapan. 16(1): 61-67.

Sulieman MS, Makawi SEA, Ibrahim KEE. 2017. Association between postpartum blood levels of glucose and urea and fertility of crossbred dairy cows in Sudan. South African J Anim Sci 47(5): 595-605.

Suwasono P, Purnomoadi A, Dartosukarno S. 2013. Kadar hematrokrit, glukosa dan urea darah sapi jawa yang diberi pakan konsentrat dengan tingkat yang berbeda. Anim Agricult J 2(4): 37-44.

Tahuk PK, Dethan AA, Sio S. 2017. Profil glukosa dan urea darah sapi bali jantan pada penggemukan dengan hijauan (Greenlot Fattening) di peternakan rakyat. Agripet 17(2): 104-111.

Thasmi CN, Siregar TN, Wahyuni S, Aliza D, Hamdan H, Panjaitan B, Asmilia N, Husnurrijal H. 2017. Estrus performance and steroid level of repeat breeding aceh cattle synchronized with Pgf2 alfa. Veterinaria 66(1): 36-41

Tillman AD, Hartadi H, Reksohadiprojo S, Prawirokusumo S, Lebdosoekojo. 1998. Ilmu Makanan Ternak Dasar. Edisi ke-5. Yogyakarta. Gadjah Mada University Press, Hlm. 17-19.

Unitly AJA. 2012. Keadaan puasa terhadap kadar glukosa darah tikus Rattus norvegicus. J Edukasi Sain Biologi 1(1): 2933.

Widayati DT, Bintara S, Natawihardja I, Maharani D. 2018. Blood biochemical profile in fertile and repeat breeder ongole cross breed cows. Pakistan J Biol Sci 21(4): 166170.

Yuherman, Reswati, Kurnia YF, Indahwati, Khalil. 2017. Hematological and mineral profiles of reproductive failure of exotic breed cattle in Payakumbuh, West Sumatra, Indonesia. Pakistan J Biol Sci 20(8): 390396.

Zaman MI, Sharma U, Razzaque WAA, Kumar S, Kumar S. 2014. Studies on certain blood biochemical constituents in normal and repeat breeding crossbred cows. Indian J Anim Reprod 35(2): 24-26. 